\title{
Plackett-Burman Design and Response Surface Methodological Approach to Optimize Basic Dyes Removal Using Sugarcane
} Bagasse

\author{
Siew Teng Ong \\ Universiti Tunku Abdul Rahman \\ Eng Cheong Khoo \\ Universiti Tunku Abdul Rahman \\ Pei Sin Keng \\ International Medical University \\ Siew Ling Hii \\ Universiti Tunku Abdul Rahman \\ Siew Ling Lee

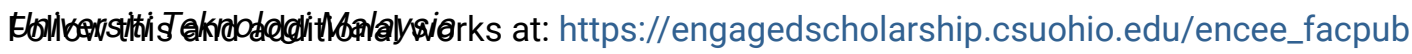 \\ How does access to this work benefit you? Let us know!

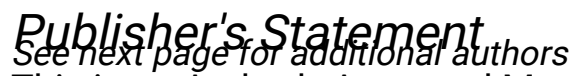 \\ This is an Author's Accepted Manuscript of an article published in Desalination and Water \\ Treatment 2011, available online: http://www.tandfonline.com/10.5004/dwt.2011.1974.
}

\section{Recommended Citation}

Ong, Siew Teng; Khoo, Eng Cheong; Keng, Pei Sin; Hii, Siew Ling; Lee, Siew Ling; and Ha, Sie Tiong, "Plackett-Burman Design and Response Surface Methodological Approach to Optimize Basic Dyes Removal Using Sugarcane Bagasse" (2011). Civil and Environmental Engineering Faculty Publications. 98. https://engagedscholarship.csuohio.edu/encee_facpub/98

This Article is brought to you for free and open access by the Civil and Environmental Engineering at EngagedScholarship@CSU. It has been accepted for inclusion in Civil and Environmental Engineering Faculty Publications by an authorized administrator of EngagedScholarship@CSU. For more information, please contact library.es@csuohio.edu. 
Authors

Siew Teng Ong, Eng Cheong Khoo, Pei Sin Keng, Siew Ling Hii, Siew Ling Lee, and Sie Tiong Ha

This article is available at EngagedScholarship@CSU: https://engagedscholarship.csuohio.edu/encee_facpub/98 


\title{
Plackett-Burman design and response surface methodological approach to optimize basic dyes removal using sugarcane bagasse
}

\author{
Siew-Teng Ong, Eng-Cheong Khoo, Pei-Sin Keng, Siew-Ling Hii, Siew-Ling Lee, \\ Yung-Tse Hung, Sie-Tiong Ha
}

\begin{abstract}
AB S T RAC T
Plackett-Burman design was applied to identify the most significant factors in the removal of Basic Blue 3 (BB3), Methylene Blue (MB) and Basic Yellow 11 (BY11) by natural sugarcane bagasse. The effect of operating parameters on dye uptake was studied in a batch system and a mathematical model showing the influence of each variable was obtained. The interaction between the factors and their optimum levels for maximum percentage uptake of BB3 and MB were determined using Response Surface Methodology (RSM). Both models were highly significant with correlation coefficients $\left(R^{2}\right)$ of 0.9932 and 0.9944 for BB3 and MB, respectively in binary dye solution. For BB3, the optimum adsorption conditions were determined as initial $\mathrm{pH} 6.00$, contact time $122.50 \mathrm{~min}$, initial dye concentration $50 \mathrm{mg} / \mathrm{L}$ and sorbent dosage $0.09 \mathrm{~g}$. Whereas for $\mathrm{MB}$, the model predicted that an uptake greater than $90 \%$ could be obtained when the initial dye concentration, contact time and sorbent dosage were set at $80.40 \mathrm{mg} / \mathrm{L}, 192.37 \mathrm{~min}$ and $0.17 \mathrm{~g}$, respectively. The percentage uptake predicted by the model was in good agreement with the experimental values.
\end{abstract}

Keywords: Sugarcane bagasse; Basic dyes; Plackett-Burman design; Response surface methodology (RSM); Optimization; Binary

\section{Introduction}

Synthetic dyes are extensively used in many industries to colour their products. Total world colourant production is estimated to be 800,000 ton/y, however at least $10 \%$ of the used dyestuff enters the environment through wastes $[1,2]$. Being highly colored, the presence of dyes even in trace quantities is aesthetically unacceptable and very undesirable in aqueous environment. Moreover, many dyes are difficult to degrade, as they are generally stable to light, oxidizing agent, and are resistant to aerobic digestion [3]. Hence, contaminations due to dyes pose not 
only a severe public health concern, but also many serious environmental problems because of their persistence in nature and nonbiodegradable characteristics.

Conventional treatment technologies for dye removal from industrial wastewater include activated sludge, chemical coagulation carbon adsorption and photodegradation process. Amongst all, the adsorption process by activated carbon is proven to be one of the most efficient methods due to its capability to adsorb many types of dyes with high adsorption capacity. However, it remains as an expensive adsorbent and has high regeneration cost while being exhausted [4].

Considerable research has been carried out in developing cost-effective techniques for the removal of dyes. One of the techniques includes the utilization of low cost materials as the biosorbents. Various agricultural wastes or by-products have been investigated intensively for their ability to remove dyes and these include orange peel $[5,6]$, rice husk [7-10], sugarcane bagasse [11], pineapple stem [12], spent tea leaves [13] and wheat straw [14]. Because of natural and abundant availability, sugarcane bagasse (SB), a major by-product of the sugar cane industry which contains about $50 \%$ cellulose, $25 \%$ hemicellulose and $25 \%$ lignin [15], is chosen as the biosorbent in this study. SB has also been previously studied for removing acid dyes such as acid red 114 and acid blue 25 [16], direct dyes [17] and reactive dyes [18].

Biosorption capacity may be significantly influenced by the operating parameters such as $\mathrm{pH}$, initial concentration, contact time and sorbent dosage. Conventional and classical methods of studying a process by maintaining other factors involved at an unspecified constant level does not describe the combined effect of all the factors involved [19]. Apart from time consuming, this method also does not guarantee the determination of optimal conditions [20,21]. These limitations of conventional methods can be eliminated by introducing statistically experiment design such as Plackett-Burman design and RSM.

Plackett-Burman design determines the most important variables for further optimization and provides unbiased estimates of linear of all variables with maximum accuracy for a given number of observations [20], whereas, RSM optimize all the affecting parameters collectively [22]. The main objective of RSM is to determine the optimum operational conditions of the system or to determine a region that satisfies the operational specifications [23]. In addition, the application of statistical experimental design techniques in adsorption process development improved product yields, reduced process variability, closer confirmation of output response to nominal and target requirements, and reduced development time and overall costs [24]. In this study, adsorption performance of sugarcane bagasse in the removal of basic dyes, namely, BB3, MB and BY11 in binary dye solutions were studied. The interaction between the factors was studied and optimized using Response Surface Methodology.

\section{Materials and methods}

\subsection{Preparation of sorbent}

Sugarcane bagasse was collected and cut into small pieces. Then the bagasse was boiled for $3 \mathrm{~h}$ to remove the sugar residue within it. It was rinsed several time with tap water and dried overnight at $60^{\circ} \mathrm{C}$. The dried bagasse was ground and sieved through a $3 \mathrm{~mm}$ sieve and labeled as NSB.

\subsection{Preparation of dye solutions}

Synthetic dye solutions of BB3, MB and BY11 were used as the sorbates in this study and their structures are illustrated in Fig. 1. The cationic dye BB3 (C.I. = 378011, $25 \%$ dye content), MB (C.I. = M9140, 82\% dye content) and BY11 (C.I. = B7133, 20\% dye content) were used without further purification. All synthetic dyes used in this study were purchased from Sigma-Aldrich Pte. Ltd., USA. Standard dyes solutions of $1000 \mathrm{mg} \mathrm{L}^{-1}$ were prepared as stock solutions and subsequently diluted when necessary.

\subsection{Plackett-Burman design}

Plackett-Burman design was used to evaluate the relative importance of various factors that influence the percentage uptake of dyes. The purpose of applying this method is to identify which factor(s) has a significant effect on the percentage uptake of the dyes. In this study, 5 assigned variables ( $\mathrm{pH}$, contact time, initial dye concentration, sorbent particle size and sorbent dosage) were screened in 12 experimental designs. Table 1 shows some<smiles>CCN(CC)c1ccc2nc3ccc(=[N+](CC)CC)cc-3oc2c1</smiles>

Basic Blue 3<smiles>CN(C)c1ccc2nc3ccc(=[N+](C)C)cc-3sc2c1</smiles><smiles>COc1ccc(NC=CC2=[N+](C)c3ccccc3C2(C)C)c(OC)c1</smiles>

Basic Yellow 11

Fig. 1. Structure of Basic Blue 3, Methylene Blue and Basic Yellow 11. 
Table 1

Plackett-Burman design and results for the removal of BB3 and MB in binary dye solutions

\begin{tabular}{|c|c|c|c|c|c|c|c|c|}
\hline \multirow[t]{2}{*}{ Dye } & \multirow{2}{*}{$\begin{array}{l}\text { Experimental } \\
\text { run }\end{array}$} & \multicolumn{5}{|c|}{ Variables } & \multirow{2}{*}{$\begin{array}{l}\text { Observed } \\
\text { response (\%) }\end{array}$} & \multirow{2}{*}{$\begin{array}{l}\text { Predicted } \\
\text { response }(\%)\end{array}$} \\
\hline & & $\mathrm{pH}$ & $\begin{array}{l}\text { Contact time } \\
(\mathrm{min})\end{array}$ & $\begin{array}{l}\text { Particle size } \\
(\mu \mathrm{m})\end{array}$ & $\begin{array}{l}\text { Dye concentration } \\
\left(\mathrm{mg} \mathrm{L}^{-1}\right)\end{array}$ & $\begin{array}{l}\text { Sorbent } \\
\text { dosage }(\mathrm{g})\end{array}$ & & \\
\hline \multirow[t]{5}{*}{ BB3 } & 1 & 3.00 & 5.00 & 850.00 & 50.00 & 0.20 & 88.33 & 84.79 \\
\hline & 2 & 9.00 & 5.00 & 850.00 & 200.00 & 0.05 & 30.01 & 31.39 \\
\hline & 3 & 9.00 & 240.00 & 850.00 & 50.00 & 0.05 & 83.93 & 79.44 \\
\hline & 4 & 9.00 & 240.00 & 150.00 & 200.00 & 0.20 & 95.66 & 94.07 \\
\hline & 5 & 9.00 & 240.00 & 150.00 & 50.00 & 0.05 & 93.40 & 91.46 \\
\hline \multirow[t]{5}{*}{$\mathrm{MB}$} & 1 & 3.00 & 5.00 & 850.00 & 50.00 & 0.20 & 88.55 & 85.43 \\
\hline & 2 & 9.00 & 240.00 & 150.00 & 50.00 & 0.05 & 93.60 & 92.54 \\
\hline & 3 & 9.00 & 240.00 & 150.00 & 200.00 & 0.20 & 96.00 & 93.18 \\
\hline & 4 & 9.00 & 240.00 & 850.00 & 50.00 & 0.05 & 84.03 & 79.49 \\
\hline & 5 & 9.00 & 5.00 & 150.00 & 50.00 & 0.20 & 96.81 & 111.60 \\
\hline
\end{tabular}

of the selected results for the removal of $\mathrm{BB} 3$ and $\mathrm{MB}$ in binary dye solutions from the 12 experimental designs. All the experiments were carried out in duplicate and the means of the percentage uptake of dyes were taken as response. The experimental design and statistical analysis of the data were done by using Design Expert Version 7.1.3.

\subsection{Optimization of percentage uptake of dye using RSM approach}

In this study, central composite design (CCD) model was used. The variables used for the studied dye at five coded levels $(-\alpha,-1,0,+1,+\alpha)$ for BB3 and MB in binary dye solutions are shown in Table 2. Some of the selected central composite design matrix of independent variables and the observed response for BB3 and MB in binary dye solutions are shown in Table 3 and 4, respectively. All the experiments were conducted in duplicate and the mean values of the duplicates were taken as the response (percentage uptake of dyes). Cubic equation used for optimization of the percentage uptake of dye is shown as follows:

$$
\begin{aligned}
Y & =\beta_{\mathrm{o}}+\sum_{i=1}^{2} \beta_{i} X_{i}+\sum_{i=1}^{2} \beta_{i i} X_{i}^{2}+\sum_{i=1}^{2} \beta_{i i i} X_{i}^{3}+\sum_{i=1}^{1} \sum_{j=i+1}^{2} \beta_{i j} X_{i} X_{j} \\
& +\sum_{i=1}^{1} \sum_{j=i+1}^{2} \beta_{i j j} X_{i} X_{j}^{2}+\sum_{i=1}^{1} \sum_{j=i+1}^{2} \beta_{i i j} X_{i}^{2} X_{j}
\end{aligned}
$$

where $\beta_{\mathrm{o}^{\prime}} \beta_{i^{\prime}} \beta_{i i^{\prime}} \beta_{i i i^{\prime}} \beta_{i j^{\prime}} \beta_{i j j}$ and $\beta_{i i j}$ are the constant coefficients, and $X_{i}$, and $X_{j}$ are the independent variables. All the experimental design and statistical analysis of the data were done by using Design Expert Version 7.1.3.

\section{Results and discussion}

\subsection{Evaluation of important variables for dyes uptake}

Plackett-Burman design was used to determine the relative importance of the various variables that affects the percentage uptake of dye. Table 5 shows the analysis

Table 2

\begin{tabular}{|c|c|c|c|c|c|c|c|}
\hline \multirow[t]{2}{*}{ Dye } & \multirow[t]{2}{*}{ Factors } & \multirow[t]{2}{*}{ Factor code } & \multicolumn{5}{|c|}{ Range and levels (coded) } \\
\hline & & & -2 & -1 & 0 & +1 & +2 \\
\hline \multirow[t]{4}{*}{ BB3 } & $\mathrm{pH}$ & A & 3.00 & 4.50 & 6.00 & 7.50 & 9.00 \\
\hline & Contact time (min) & $\mathrm{B}$ & 5.00 & 63.75 & 122.50 & 181.25 & 240.00 \\
\hline & Sorbent dosage (g) & $\mathrm{C}$ & 0.05 & 0.08 & 0.09 & 0.16 & 0.20 \\
\hline & Initial dye concentration $\left(\mathrm{mg} \mathrm{L}^{-1}\right)$ & $\mathrm{D}$ & 50.00 & 87.50 & 125.00 & 162.50 & 200.00 \\
\hline \multirow[t]{4}{*}{$\mathrm{MB}$} & & & -1.682 & -1 & 0 & +1 & +1.682 \\
\hline & Contact time (min) & $\mathrm{B}$ & 5.00 & 52.63 & 122.50 & 192.37 & 240.00 \\
\hline & Sorbent dosage (g) & $\mathrm{C}$ & 0.05 & 0.08 & 0.09 & 0.17 & 0.20 \\
\hline & Initial dye concentration $\left(\mathrm{mg} \mathrm{L}^{-1}\right)$ & $\mathrm{D}$ & 50.00 & 80.40 & 125.00 & 169.60 & 200.00 \\
\hline
\end{tabular}

Experimental range and levels of independent variables of BB3 and MB dye in binary dye solutions 
Table 3

The central composite design matrix for four independent variables and the observed response for BB3 in binary dye solution

\begin{tabular}{|c|c|c|c|c|c|c|}
\hline \multirow{2}{*}{$\begin{array}{l}\text { Experimental } \\
\text { run }\end{array}$} & \multicolumn{4}{|c|}{ Coded values of variables } & \multirow{2}{*}{$\begin{array}{l}\text { Observed } \\
\text { response (\%) }\end{array}$} & \multirow{2}{*}{$\begin{array}{l}\text { Predicted } \\
\text { response }(\%)\end{array}$} \\
\hline & $A$ & $B$ & C & $D$ & & \\
\hline 1 & 0 & 0 & -2 & 0 & 46.82 & 46.61 \\
\hline 3 & 0 & 2 & 0 & 0 & 79.88 & 78.37 \\
\hline 4 & 0 & 0 & 2 & 0 & 89.80 & 89.59 \\
\hline 5 & -2 & 0 & 0 & 0 & 53.63 & 53.42 \\
\hline 6 & 0 & -2 & 0 & 0 & 70.53 & 71.64 \\
\hline 7 & 2 & 0 & 0 & 0 & 84.33 & 84.12 \\
\hline 8 & 1 & 1 & -1 & 1 & 61.35 & 61.79 \\
\hline 9 & 1 & -1 & -1 & 1 & 57.05 & 57.03 \\
\hline 10 & 1 & 1 & 1 & 1 & 77.51 & 77.93 \\
\hline 11 & -1 & -1 & -1 & -1 & 65.34 & 65.33 \\
\hline 12 & -1 & 1 & -1 & -1 & 69.42 & 69.85 \\
\hline 13 & 1 & -1 & -1 & -1 & 69.50 & 70.12 \\
\hline 14 & -1 & -1 & 1 & -1 & 86.48 & 86.04 \\
\hline 15 & -1 & 1 & 1 & 1 & 69.60 & 68.98 \\
\hline 16 & 1 & -1 & 1 & -1 & 89.39 & 88.32 \\
\hline 17 & 0 & 0 & 0 & 0 & 72.84 & 74.49 \\
\hline 18 & 0 & 0 & 0 & 0 & 73.18 & 74.49 \\
\hline 19 & 0 & 0 & 0 & 0 & 75.09 & 74.49 \\
\hline 20 & 0 & 0 & 0 & 0 & 73.81 & 74.49 \\
\hline 21 & 0 & 0 & 0 & 0 & 73.74 & 74.49 \\
\hline 22 & 0 & 0 & 0 & 0 & 74.51 & 74.49 \\
\hline
\end{tabular}

Table 4

The central composite design matrix for three independent variables and the observed response for MB in binary dye solution

\begin{tabular}{|c|c|c|c|c|c|}
\hline \multirow[t]{2}{*}{ Experimental run } & \multicolumn{3}{|c|}{ Coded values of variables } & \multirow{2}{*}{$\begin{array}{l}\text { Observed response } \\
(\%)\end{array}$} & \multirow{2}{*}{$\begin{array}{l}\text { Predicted response } \\
(\%)\end{array}$} \\
\hline & $B$ & $C$ & $D$ & & \\
\hline 1 & 0 & 0 & -1.682 & 57.89 & 56.75 \\
\hline 2 & 1.682 & 0 & 0 & 78.35 & 77.44 \\
\hline 3 & 0 & 0 & 1.682 & 93.44 & 94.22 \\
\hline 4 & 0 & 1.682 & 0 & 88.65 & 87.55 \\
\hline 5 & 0 & -1.682 & 0 & 42.97 & 42.61 \\
\hline 6 & -1.682 & 0 & 0 & 66.82 & 66.27 \\
\hline 7 & -1 & -1 & 1 & 38.64 & 39.41 \\
\hline 8 & 1 & 1 & -1 & 92.66 & 95.06 \\
\hline 9 & -1 & 1 & -1 & 90.27 & 88.41 \\
\hline 10 & 1 & -1 & -1 & 76.60 & 74.92 \\
\hline 11 & 1 & 1 & 1 & 78.45 & 79.35 \\
\hline 12 & 1 & -1 & 1 & 45.30 & 46.05 \\
\hline 13 & -1 & 1 & 1 & 71.46 & 72.71 \\
\hline 14 & -1 & -1 & -1 & 66.68 & 68.27 \\
\hline 15 & 0 & 0 & 0 & 75.55 & 75.48 \\
\hline 16 & 0 & 0 & 0 & 75.17 & 75.48 \\
\hline 17 & 0 & 0 & 0 & 75.66 & 75.48 \\
\hline 18 & 0 & 0 & 0 & 76.48 & 75.48 \\
\hline 19 & 0 & 0 & 0 & 74.45 & 75.48 \\
\hline 20 & 0 & 0 & 0 & 76.46 & 75.48 \\
\hline
\end{tabular}


Table 5

Regression analysis (ANOVA) of Plackett-Burman of BB3 and MB in binary dye solutions

\begin{tabular}{|c|c|c|c|c|c|c|}
\hline Dye & Source & $\begin{array}{l}\text { Degree of } \\
\text { freedom }\end{array}$ & Sum of square & Mean square & $F$-value & Prob $>F$ \\
\hline \multirow[t]{8}{*}{ BB3 } & Model & 5 & 8600.89 & 1720.18 & 20.04 & 0.0011 \\
\hline & $\mathrm{pH}$ & 1 & 595.73 & 595.73 & 6.94 & 0.0388 \\
\hline & Contact time & 1 & 731.48 & 731.48 & 8.52 & 0.0267 \\
\hline & Particle size & 1 & 433.08 & 433.08 & 5.04 & 0.0658 \\
\hline & Dye concentration & 1 & 3155.44 & 3155.44 & 36.76 & 0.0009 \\
\hline & Sorbent dosage & 1 & 3685.16 & 3685.16 & 42.93 & 0.0006 \\
\hline & Residual & 6 & 515.07 & 85.85 & & \\
\hline & Total & 11 & 9115.96 & & & \\
\hline \multirow[t]{8}{*}{$\mathrm{MB}$} & Model & 5 & 8499.37 & 1699.87 & 16.99 & 0.017 \\
\hline & $\mathrm{pH}$ & 1 & 516.67 & 516.67 & 5.17 & 0.0634 \\
\hline & Contact time & 1 & 669.01 & 669.01 & 6.69 & 0.0414 \\
\hline & Particle size & 1 & 510.39 & 510.39 & 5.10 & 0.0647 \\
\hline & Initial dye concentration & 1 & 3336.64 & 3336.64 & 33.36 & 0.0012 \\
\hline & Sorbent Dosage & 1 & 3466.64 & 3466.64 & 34.66 & 0.0011 \\
\hline & Residual & 6 & 600.19 & 100.03 & & \\
\hline & Total & 11 & 9099.56 & & & \\
\hline
\end{tabular}

of variance (ANOVA) results of BB3 and $\mathrm{MB}$ in binary dye solutions. From the same table, the model $F$-value of 20.40 and Prob > F of 0.0011 indicates that the model was significant. Model terms were determined as significant when the value of Prob $>F$ was less than 0.05. For BB3, $\mathrm{pH}$, contact time, initial dye concentration and sorbent dosage were the model terms which were significant, while, particle size was not significant for the response (Prob $>F=0.0658)$. For MB, the model was significant with $F$-value of 16.99 and Prob $>F$ of 0.017 as shown in Table 5. Contact time, initial dye concentration and sorbent dosage were the significant model terms for MB. For BY11 in both BB3-BY11 and MB-BY11 dye solutions, both models were insignificant as both $P r o b>F$ values were greater than 0.05 . All the studied factors were not significant for BY11 in both binary dye solutions. Operation conditions: $\mathrm{pH}$, initial dye concentration, contact time and sorbent dosage were reported as important factors which influenced the percentage uptake of dyes in conventional batch study $[8,12]$.

\subsection{Verification of Plackett-Burman design models}

The function of desirability was applied using Design-Expert Version 7.1.3 to validate the models. The experimental conditions having the highest desirability were chosen to be verified and the experimental results obtained agreed well with the predicted values for both models. The percentage errors between the actual and predicted values were $5.33 \%$ and $3.80 \%$ for $\mathrm{BB} 3$ and $\mathrm{MB}$, respectively in binary dye solutions. The models of BY11 in both MB-BY11 and BB3-BY11 dye solutions were not verified due to their insignificancy of the models.

\subsection{Data analysis by RSM}

The effect of $\mathrm{pH}$, contact time, initial dye concentrations and sorbent dosage on the percentage uptake of BB3 and the effect of contact time, initial dye concentration and sorbent dosage on percentage uptake of MB in binary dye solution were studied using RSM. The modified cubic models describing the correlation between the variables and the percentage uptake for both dyes were shown as follows:

BB3 in binary dye solution:

$$
\begin{aligned}
\% \text { uptake } & =82.929-4.316 A-1.185 B+18.880 C \\
& +0.213 D+0.207 A B+206.820 A C \\
& -0.175 A D-0.288 B C-0.393 A^{2} \\
& +0.00495 B^{2}-1136.453 C^{2}-18.162 A^{2} C \\
& +0.0162 A^{2} D-0.000819 A B^{2}
\end{aligned}
$$

MB in binary dye solution:

$$
\begin{aligned}
\% \text { uptake } & =56.447+0.112 B+555.260 C-0.457 D \\
& +1.655 C D-2.627 B^{2}-1849.941 C^{2}
\end{aligned}
$$

where $A=\mathrm{pH}, B=$ contact time, $C=$ sorbent dosage and $D=$ initial dye concentration.

Tables 6 and 7 show the ANOVA regression analysis for both BB3 and MB in binary dye solutions. Both models were significant $(P<0.0001)$ with $F$-value of 156.95 
Table 6

Regression analysis (ANOVA) for the removal of BB3 from binary dye solution

\begin{tabular}{|c|c|c|c|c|c|}
\hline Source & Degree of freedom & Sum of square & Mean square & $F$-value & $P$ \\
\hline Model & 14 & 4906.44 & 350.46 & 156.95 & $<0.0001$ \\
\hline$A$ & 1 & 471.15 & 471.15 & 211.00 & $<0.0001$ \\
\hline$B$ & 1 & 67.91 & 67.91 & 30.41 & $<0.0001$ \\
\hline C & 1 & 923.63 & 923.63 & 413.64 & $<0.0001$ \\
\hline$D$ & 1 & 706.71 & 706.71 & 316.49 & $<0.0001$ \\
\hline$A B$ & 1 & 4.77 & 4.77 & 2.14 & 0.1646 \\
\hline$A C$ & 1 & 6.27 & 6.27 & 2.18 & 0.1146 \\
\hline$A D$ & 1 & 20.20 & 20.20 & 9.05 & 0.0088 \\
\hline$B C$ & 1 & 6.45 & 6.45 & 2.89 & 0.1098 \\
\hline$A^{2}$ & 1 & 57.32 & 57.32 & 25.67 & 0.0001 \\
\hline$B^{2}$ & 1 & 0.45 & 0.45 & 0.20 & 0.6585 \\
\hline$C^{2}$ & 1 & 71.51 & 71.51 & 32.03 & $<0.0001$ \\
\hline$A^{2} C$ & 1 & 12.52 & 21.52 & 5.61 & 0.0317 \\
\hline$A^{2} D$ & 1 & 9.99 & 9.99 & 4.47 & 0.0516 \\
\hline$A B^{2}$ & 1 & 95.82 & 95.82 & 42.91 & $<0.0001$ \\
\hline Residual & 15 & 33.49 & 2.23 & & \\
\hline Lack of fit & 10 & 30.04 & 3.00 & 4.34 & 0.0593 \\
\hline
\end{tabular}

$R^{2}: 0.9932$, Adjusted $R^{2}: 0.9869$, Predicted $R^{2}: 0.9653$, Adequate precision: 44.178 and C.V.: $2.07 \%$

Table 7

Regression analysis (ANOVA) for the removal of MB from binary dye solution

\begin{tabular}{lccrrr}
\hline Source & Degree of freedom & Sum of square & Mean square & $F$-value & $P$ \\
\hline Model & 6 & 4580.77 & 763.46 & 387.56 & $<0.0001$ \\
$A$ & 1 & 150.68 & 150.68 & 76.49 & $<0.0001$ \\
$B$ & 1 & 2437.88 & 2437.88 & 1237.55 & $<0.0001$ \\
$C$ & 1 & 1695.35 & 1695.35 & 860.62 & $<0.0001$ \\
$B C$ & 1 & 86.62 & 86.62 & 43.97 & $<0.0001$ \\
$A^{2}$ & 1 & 23.93 & 23.93 & 12.15 & 0.0040 \\
$B^{2}$ & 1 & 197.00 & 197.00 & 100.01 & $<0.0001$ \\
Residual & 13 & 25.61 & 1.97 & & 0.0529 \\
Lack of fit & 8 & 22.59 & 2.82 & 4.68 &
\end{tabular}

$R^{2}: 0.9944$, Adjusted $R^{2}: 0.9919$, Predicted $R^{2}: 0.9838$, Adequate precision: 67.018 and C.V.: $1.95 \%$

and 387.56 for BB3 and MB, respectively. Coefficient of determination $\left(R^{2}\right)$ for BB3 was found to be 0.9932 while the rest $(0.68 \%)$ was explained as residues. On the other hand, $R^{2}$ for MB was reported as 0.9944 . Both of the $R^{2}$ values were relatively high, showing that there were good agreements between the experimental and predicted values in both models. The closer the $R^{2}$ is to unity, the stronger the model and the better it predicts the response [25]. The predicted multiple correlation coefficient (predicted $R^{2}$ ) value of 0.9653 is reasonable agreement with the adjusted multiple correlation coefficient (adjusted $R^{2}$ ) value of 0.9869 for BB3. Meanwhile, the value of predicted
$R^{2}(0.9838)$ also agreed reasonably with the adjusted $R^{2}$ (0.9919) for MB.

The lack-of-fit observed for BB3 and MB models were 0.0593 and 0.0529 , respectively. The not significant in lackof-fit implies that the model was valid. The coefficient of variance (C.V.) of BB3 model was reported as $2.07 \%$. Meanwhile, the C.V. for MB model was $1.95 \%$. The lower of the C.V. value, the greater is the precision and reliability of the experiments carried out [26]. Adequate precision indicates the signal to noise ratio and a ratio greater than 4 is desirable. A ratio of 44.178 and 67.018 obtained for $\mathrm{BB} 3$ and MB, respectively, showed an adequate signal. 
Thus, both models can be used to navigate the design space. Table 6 shows all the coefficients were significant $(P<0.05)$ except $A B, A C, B C, B^{2}$ and $A^{2} D, A B, A C, B C$, $B^{2}$ and $A^{2} D$; however it cannot be eliminated in order to support the hierarchy model. For MB model (Table 7), all the coefficients were significant. BY11 in both BB3BY11 and MB-BY11 dye solutions were not studied using RSM due to the insignificancy of all the studied factors at Plackett-Burman studies.

The interaction between two factors and their optimum levels can be easily understood and located using response surface plot [26]. Fig. 2 shows the 3D surface plot for BB3 binary dye solution of interaction between $\mathrm{pH}$ and initial dye concentration at contact time of 122.50 min and $0.16 \mathrm{~g}$ of sorbent dosage. The maximum percentage uptake of BB3 dye was observed when initial dye concentration was at minimum point while $\mathrm{pH}$ was at maximum point within the studied range. As the initial dye concentration increased the percentage uptake decreased. Decrease in percentage uptake at high initial dye concentration might be due to insufficient of available binding sites and increase in the ratio of the BB3's cations to the adsorbent adsorbent. Similar observation was observed in the removal of Methylene Blue [27]. Maximum percentage uptake was observed at higher $\mathrm{pH}$ due to the increase number of negatively charged sites. The surface charge may be positively charged at lower $\mathrm{pH}$, therefore making $\left(\mathrm{H}^{+}\right)$ions compete effectively with dye causing a decline in the percentage uptake [12].

Fig. 3 exhibits the 3D surface plot for BB3 binary dye solution of interaction between $\mathrm{pH}$ and sorbent dosage at contact time of $122.50 \mathrm{~min}$ and initial dye concentration of $100 \mathrm{mg} / \mathrm{g}$. Maximum percentage uptake was attained when both $\mathrm{pH}$ and sorbent dosage were at maximum level. Increase in sorbent dosage led to an increase in the

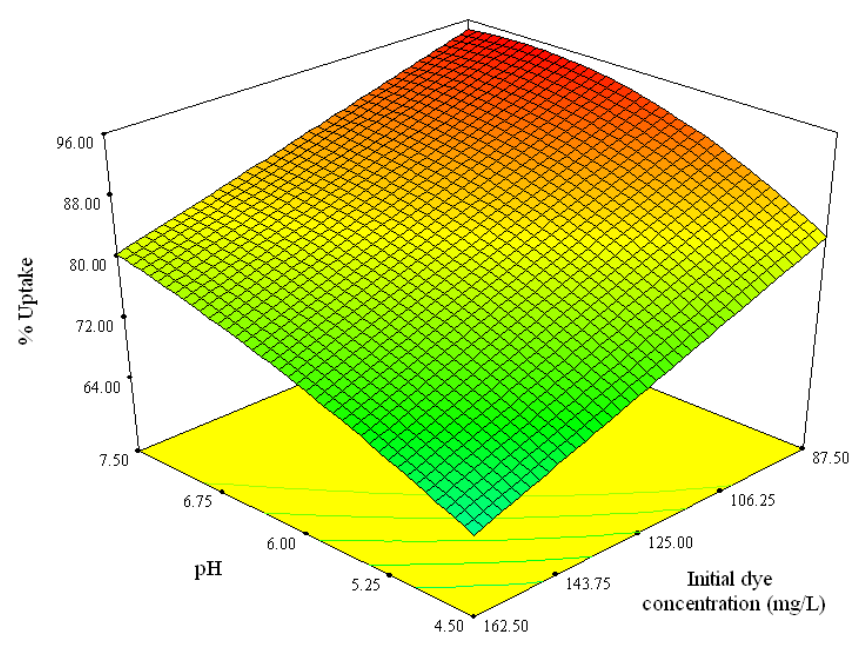

Fig. 2. 3D surface plot for uptake of BB3 in binary dye solution as a function of $\mathrm{pH}$ and initial dye concentration at contact time of $122.50 \mathrm{~min}$ and $0.16 \mathrm{~g}$ of sorbent dosage.

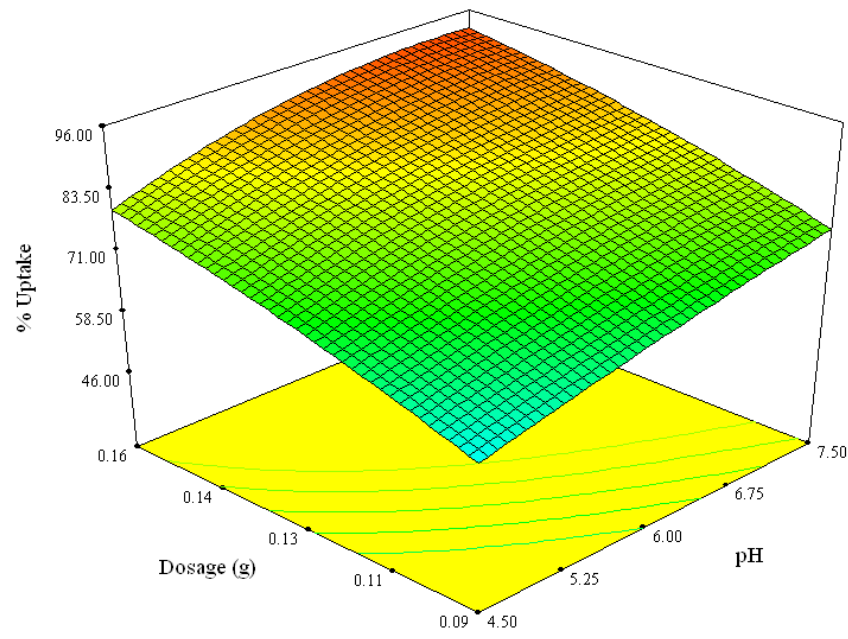

Fig. 3. 3D surface plot for uptake of BB3 in binary dye solution as a function of $\mathrm{pH}$ and dosage at contact time of $122.50 \mathrm{~min}$ and $100 \mathrm{mg} / \mathrm{g}$ of initial dye concentration.

percentage uptake of dyes and this could be explained by an increase in sorbent sites against the available sorbate. Similar observation was reported in the removal of basic and reactive dyes [8]. As $\mathrm{pH}$ increased, sorption became favorable due to the deprotonation of the carboxyl groups $\left(-\mathrm{COO}^{-}\right)$, resulting in sorption sites that were available for binding with $\mathrm{BB} 3$ [8]. With increasing $\mathrm{pH}$, the number of positively charged sites decreased and the number of negatively charged sites increased [8]. This phenomenon favors the sorption of positively charged dye due to electrostatic attraction $[8,27]$.

Fig. 4 shows the 3D surface plot for BB3 binary dye solution of interaction between contact time and sorbent dosage at $\mathrm{pH}$ of 6 and initial dye concentration of 100 $\mathrm{mg} / \mathrm{g}$. From the 3D plot, maximum percentage uptake was observed when both contact time and sorbent dosage were at maximum point. Minimal changes in percentage uptake were observed as the contact time increased. This shows that the equilibrium time of sorption was reached at the studied contact time frame and the percentage uptake remained almost constant. The time required to attain equilibrium was termed as equilibrium time, and the amount of dye adsorbed at equilibrium time reflects the maximum adsorption capacity of the adsorbent [28]. The optimum values of experiment factors obtained were $\mathrm{pH} 6,122.50 \mathrm{~min}$ of contact time, $0.09 \mathrm{~g}$ of sorbent dosage and $50 \mathrm{mg} / \mathrm{L}$ of initial dye concentration. At these optimum operational values, the model predicted $93.29 \%$ uptake.

Fig. 5 represents the 3D surface plot for MB binary dye solution of interaction between sorbent dosage and initial dye concentration at contact time of $122.50 \mathrm{~min}$. From the $3 \mathrm{D}$ plot, the maximum percentage uptake was obtained when the load of sorbent dosage was at maximum while the initial dye concentration at minimum. The percentage 


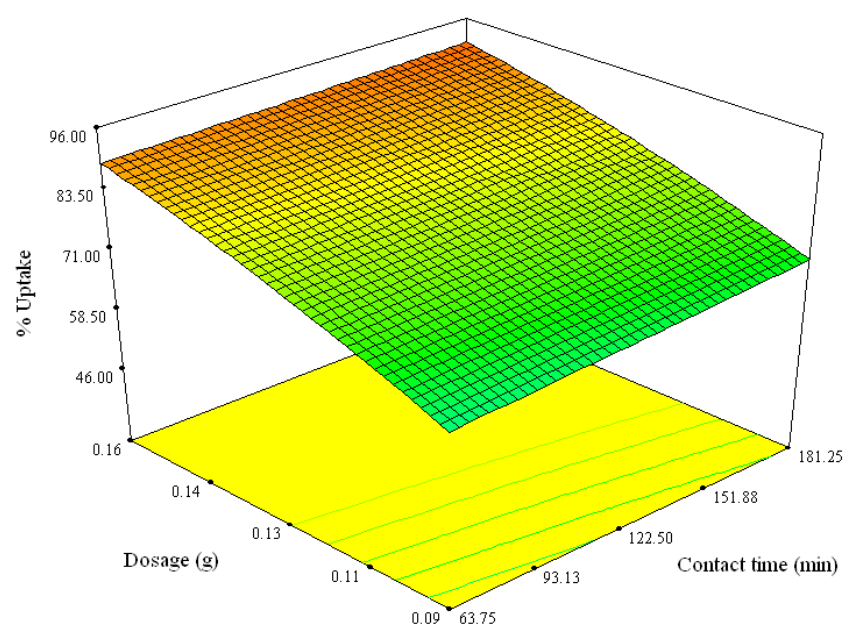

Fig. 4. 3D surface plot for uptake of BB3 in binary dye solution as a function of contact time and dosage at initial dye concentration of $100 \mathrm{mg} / \mathrm{g}$ and $\mathrm{pH}$ of 6 .

uptake increased as the dosage of sorbent increased. This was due to the increase of the binding sites as the sorbent dosage increased. Similar observation was obtained in the removal of Basic Yellow 11 using Sargassum binderi [29] and basic dyes using NTA sugarcane bagasse [30]. Optimum operational values were reported as $192.37 \mathrm{~min}$ of contact time, $0.17 \mathrm{~g}$ of sorbent dosage and $80.40 \mathrm{mg} / \mathrm{L}$ of initial dye concentration. The model predicted $95.06 \%$ uptake at these optimum operational values.

\subsection{Verification of RSM models}

In order to determine the validation of the model equations for both studied dyes, experiments were conducted based on the experimental conditions with the highest desirability which generated by Design Expert v.7.1.3 software. From the experimental results obtained, the percentage uptake for BB3 and MB in binary dye solutions were $94.33 \%$ and $91.85 \%$, respectively. Both of the results were closed to the predicted results with percentage errors of $0.99 \%$ and $1.54 \%$ for binary BB3 and binary $\mathrm{MB}$, respectively. Hence, both models can be concluded as valid. Similar observation was reported by Wang and Hsieh [31].

\section{Conclusion}

The optimization and the modeling of percentage uptake of BB3, MB and BY11 in binary dye solutions were conducted using Plackett-Burman design and RSM. Plackett-Burman design was successfully applied to identify the most significant factors which influence the percentage uptake of the dyes. By using RSM, a set of optimal reaction conditions for BB3 uptake was obtained

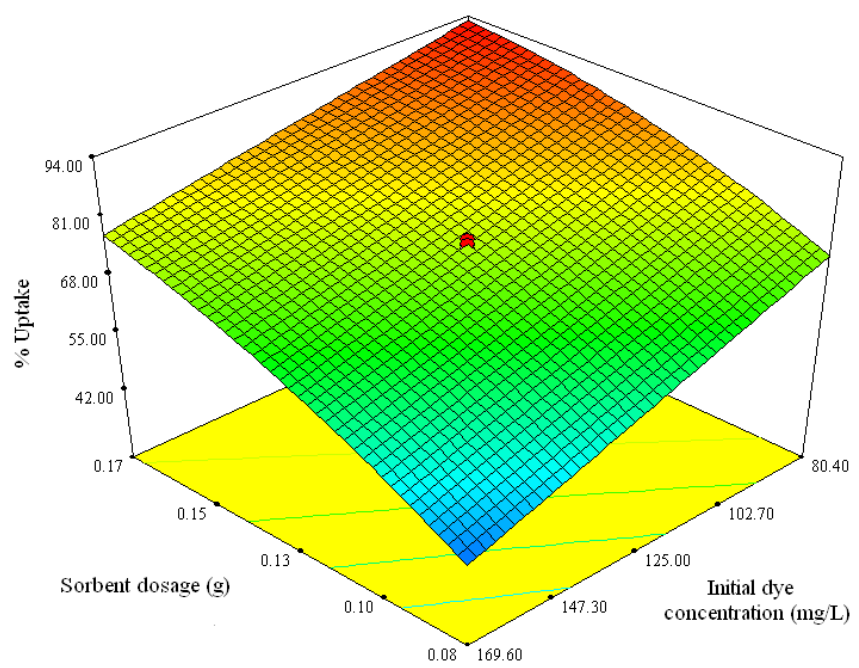

Fig. 5. 3D surface plot for uptake of $\mathrm{MB}$ in binary dye solution as a function of sorbent dosage and initial dye concentration at contact time of $122.50 \mathrm{~min}$.

with the compromise of these responses: $\mathrm{pH}(6.00)$, contact time (122.50 min), initial dye concentration $(50 \mathrm{mg} / \mathrm{L})$ and sorbent dosage $(0.09 \mathrm{~g})$. Meanwhile, the optimal conditions for MB uptake were identified as $192.37 \mathrm{~min}$ of contact time, $80.40 \mathrm{mg} / \mathrm{L}$ of initial dye concentration and $0.17 \mathrm{~g}$ of sorbent dosage. Under optimal values of operating parameters, high percentage uptake of both dyes was achieved $(>90 \%)$. The model employed provided good quality of predictions in terms of dye uptake and correlation coefficients.

\section{Acknowledgement}

The financial support by the International Foundation of Science, Stockholm, Sweden, and the Organisation for the Prohibition of Chemical Weapons, The Hague, The Netherlands via grant no. W/4368-1 and teaching assistantship for E.C. Khoo from Universiti Tunku Abdul Rahman (UTAR) are gratefully acknowledged.

\section{References}

[1] L. Levin, L. Papinutti and F. Forchiassin, Evaluation of Argentinean white rot fungi for their ability to produce lignin-modifying enzymes and decolorize industrial dyes. Bioresour. Technol., 94 (2004) 169-176.

[2] G. Palmieri, G. Cennamo and G. Sannia, Remozal Brilliant R decolourisation by the fungus Pleurorus ostreatus and its oxidative enzymatic system. Enzyme Microb. Technol., 36 (2005) 17-27.

[3] G. McKay and A. Sweeny, Principles of dye removal from textile effluent. Water, Air, Soil Pollut., 14 (1980) 3-11.

[4] R.P. Han, D.D. Ding, Y.F. Xu, W.H. Zou, Y.F. Wang, Y. Li and L.N. Zou, Use of rice husk for the adsorption of congo red from aqueous solution in column mode. Bioresour. Technol., 99 (2008) 2938-2946.

[5] M. Arami, N.Y. Limaee, N.M. Mahmoodi and N.S. Tabrizi, Re- 
moval of dyes from colored textile wastewater by orange peel adsorbent: Equilibrium and kinetic studies. J. Colloid Interf. Sci., 228 (2005) 371-376.

[6] F.D. Ardejani, K. Badii, N.Y. Limaee, N.M. Mahmoodi, M. Arami, S.Z. Shafaei and A.R. Mirhabibi, Numerical modelling and laboratory studies on the removal of Direct Red 23 and Direct Red 80 dyes from textile effluents using orange peel, a low cost adsorbent. Dyes Pigments, 73 (2007) 178-185.

[7] R.P. Han, Y.F. Wang, W.H. Yu, W.H. Zou, J. Shi and H.M. Liu, Biosorption of methylene blue from aqueous solution by rice husk in a fixed-bed column. J. Hazard. Mater., 141 (2007) 713-718.

[8] S.T. Ong, C.K. Lee and Z. Zainal, Removal of basic and reactive dyes using ethylenediamine modified rice hull. Bioresour. Technol., 98 (2007) 2792-2799.

[9] C.K. Lee, S.T. Ong and Z. Zainal, Ethylenediamine modified rice hull as sorbent for the removal of Basic Blue 3 and Reactive Orange 16. Int. J. Environ. Pollut., 34 (2008) 246-260.

[10] S.T. Ong, E.H. Tay, S.T. Ha, W.N. Lee and P.S. Keng, Equilibrium and continuous flow studies on the sorption of Congo Red using ethylenediamine modified rice hulls. Int. J. Phys. Sci., 4 (2009) 683-690.

[11] S.T. Ong, S.T. Ha, E.C. Khoo and S.L. Hii, Nitrilotriacetic acid modified sugarcane bagasse in the removal of Basic Blue 3 from aqueous environment. Int. J. Environ. Eng., in press.

[12] B.H. Hameed, R.R. Krishni and S.A. Sata, A novel agricultural waste adsorbent for the removal of cationic dyes from aqueous solutions. J. Hazard. Mater., 162 (2009) 305-311.

[13] B.H. Hameed, Spent tea leaves: A new non-conventional and low-cost adsorbent for removal of basic dye from aqueous solutions. J. Hazard. Mater., 161 (2009) 753-759.

[14] R.M. Gong, S.X. Zhu, D.M. Zhang, J. Chen, S.J. Ni and R. Guan, Adsorption behaviour of cationic dyes on citric acid esterifying wheat straw: Kinetic and thermodynamic profile. Desalination, 230 (2008) 220-228.

[15] Y. Xing and G. Wang, Poly(methacrylic acid)-modified sugarcane bagasse for enhanced adsorption of cationic dye. Environ. Technol., 30 (2009) 611-619.

[16] G. McKay, M. El-Geundi and M.M. Nassar, Equilibrium studies during the removal of dyestuffs from aqueous solutions using bagasse pith. Wat. Res., 21 (1987) 1513-1520.

[17] I. Abd-El-Thalouth, M.M. Kamel, K. Haggag and M. El-Zawahry, Utilizing sugar-cane bagasse pulp and carbamoyl ethyl derivatives as direct dye absorbent. Am. Dyestuff Reporter, 82 (1993) 36-41.
[18] J.A. Laszlo, Preparing an ion exchange resin from sugarcane bagasse to remove reactive dye from wastewater. Text. Chemist Colorist, 28 (1996) 13-17.

[19] K. Ravikumar, S. Ramalingam, S. Krishnan and K. Balu, Application of response surface methodology to optimize the process variables for Reactive Red and Acid Brown dye removal using novel adsorbent. Dyes Pigments, 70 (2006) 18-26.

[20] A. Rajendran, M. Thirugnanam and V. Thangavelu, Statistical evaluation of medium components by Plackett-Burman experimental design and kinetic modeling of lipase production by Pseudomonas fluoresceens. Indian J. Biotech., 6 (2007) 467-478.

[21] U.K. Garg, M.P. Kaur, V.K. Gard and D. Sud, Removal of nickel(II) from aqueous solution by adsorption on agricultural waste biomass using a response surface methodological approach. Bioresour. Technol., 99 (2008) 1325-1331.

[22] E. Murat, Response surface methodological approach for inclusion of perfluorocarbon in actinorhodin fermentation medium. Process Biochem., 38 (2002) 667-773.

[23] R.H. Myers and D.C. Montgomery, Response Surface Methodology, 2nd ed., John Wiley and Sons Inc., 2002.

[24] G. Annadurai, R.S. Juang and D.J. Lee, Adsorption of heavy metals from water using banana and orange peels. Wat. Sci. Technol., 47 (2003) 185-190.

[25] K. Chauhan, U. Trivedi and K.C. Patel, Application of response surface methodology for optimization of lactic acid production using date juice. J. Microb. Biotechnol., 16 (2006) 1410-1415.

[26] J.K. Kim, B.R. Oh, H. Shin, C. Eom and S.W. Kim, Statistical optimization of enzymatic saccharification and ethanol fermentation using food waste. Process Biochem., 43 (2008) 1308-1312.

[27] F.A. Batzias and D.K. Sidiras, Simulation of dye adsorption by beech sawdust as affected by pH. J. Hazard. Mater., 141 (2007) 668-679.

[28] A.A. Ahmad, B.H. Hameed and N. Aziz, Adsorption of direct dye on palm ash: Kinetic and equilibrium modeling. J. Hazard. Mater., 141 (2007) 70-76.

[29] P.L. Tan, C.L. Wong, S.T. Ong and S.L. Hii, Equilibrium and Kinetic Studies for Basic Yellow 11 Removal by Sargassum binderi. J. Appl. Sci., 9 (2009) 3005-3012.

[30] S.T. Ong, E.C. Khoo, S.L. Hii and S. T. Ha, Utilization of sugarcane bagasse for removal of basic dyes from aqueous environment in single and binary systems. Desal. Wat. Treat., 20 (2010) 86-95.

[31] J.K. Wang and C.S. Hsieh, Determination of optimal conditions for separation of metal ions through membrane dialysis using statistical experimental methods. Desal. Wat. Treat., 2 (2009) 246-253. 